УДК 377.1:370.1

DOI:

Марина Агапова, кандидат педагогічних наук, доиент кафедри соиіальної політики Національного педагогічного університету імені М.П. Драгоманова, м. Київ

\title{
ФОРМУВАННЯ ІНФОРМАЦІЙНО-АНАЛІТИЧНОӤ КОМПЕТЕНТНОСТІ УЧНІВ ПРОФЕСІЙНО-ТЕХНІЧНИХ НАВЧАЛЬНИХ ЗАКЛАДІВ ШЛЯХОМ АКТИВІЗАЦІЇ НАВЧАННЯ
}

У статті обтрунтовано доцільність використання методів і прийомів активізаиії навчання у процесі фахової підготовки майбутніх кваліфікованих робітників. Представлено сутність поняття і структуру інформачійно-аналітичної компетентності учнів професійно-технічних навчальних закладів. Визначено роль інтерактивних методів навчання у формуванні інформаційно-аналітичної компетентності майбутніх робітників. Основну увагу приділено методу ситуаційного навчання (кейс-методу) та методу проектів, щэо є ключовими у контексті досліджуваної проблеми; представлено їх поєднання з іншими методами навчання.

Ключові слова: інформачійно-аналітична компетентність; активізація навчання; кейс-метод; метод проектів.

Jim. 7.

Maryna Ahapova, Ph.D.(Pedagogy), Associate Professor of the Social Policy Department National Mykhaylo Drahomanov Pedagogical University

\section{FORMATION OF INFORMATIONAL-ANALYTICAL COMPETENCE OF STUDENTS OF VOCATIONAL EDUCATIONAL INSTITUTIONS BY ACTIVATING OFTRAINING}

The article substantiates the expediency of using the methods and techniques by activating of training in the process of professional training of future skilled workers.

The concept "informational-analytical competence of students of vocational and technical educational institutions" is presented. It is noted that within the research the structure of the informational-analytical competence contains the following components: value-motivational; cognitive; functional; reflexive.

The role of interactive teaching methods in the formation of informational-analytical competence of students of vocational and technical educational institutions is determined. The main attention is paid to the method of situational learning (case-method) and the method of projects that are key elements in the context of the problem under the study. It is presented their combination with other learning methods, such as, "brainstorming" and business game.

It is noted that in comparison with the traditional teaching methods, the case technology allows more successfully to develop the creative abilities of students, forms the skills of performing the complex tasks in small groups, helps students to successfully master the skills to analyze non-standard situations, independently develop algorithms for decision making. This method contributes to the development of technical thinking, the ability to freely orient in modern production, readiness for productive professional activity, the formation of such qualities as initiative and independence.

The method of projects includes a set of educational and cognitive methods of creative nature (researching, searching, problematic, etc.), which allow solving a certain problems through independent action of students with a mandatory presentation of the results in the form of a material project. The leading idea of the method is active learning, which would be based on the student's interests. The basis of the method of projects is the development of cognitive and professional interests of students, the ability to independently construct their knowledge, ability to navigate the information space, the development of critical thinking.

It is proved that the using of thec considered interactive methods based on the dialogue, cooperation of all subjects of the education in the process of professional training of future specialists, contributes to the formation of all components of the structure of informational-analytical competence.

Keywords: an informational and analytical competence; activating of training; the case-method; the project method.

П остановка проблеми. Перспективи розвитку економіки та соціальної сфери країни посилюють роль професійно-технічної освіти як динамічної системи, спрямованої на задоволення пізнавальних потреб особистості, створення умов для їі вдосконалення в конкретних видах професійної діяльності протягом усього життя, що декларовано у законах України “Про освіту”, “Про професійно-технічну освіту”, Концепції розвитку професійно-технічної (професійної) освіти в Україні, Концепції державної системи професійної орієнтації населення.

Водночас, швидкі темпи інформатизації та глобалізації суспільства, зокрема, збільшення обсягу інформації, поява нових інформаційних 


\section{ФОРМУВАННЯІНФОРМАЦІЙНО-АНАЛТТИЧНОӦ КОМПЕТЕНТНОСТІ УЧНІВ ПРОФЕСЙНО-ТЕХНІЧНИХ НАВЧАЛЬНИХЗАКЛАДІВ ШЛЯХОМ АКТИВІЗАЦІЇ НАВЧАННЯ}

ресурсів, методів і засобів їі оброблення та зберігання, вимагають значного підвищення якості професійної підготовки кваліфікованих робітників, iii фундаменталізації та гнучкості у зазначеному контексті. Це актуалізує проблему формування інформаційно-аналітичної компетентності майбутніх фахівців, здатних знаходити, якісно аналізувати, порівнювати, структурувати, узагальнювати отриману інформацію, оцінювати та представляти їі результати. Останнє зумовлює потребу в оновленні традиційних методів навчання у професійно-технічних закладах освіти, удосконаленні методів і прийомів активізації пізнавальної діяльності майбутніх робітників.

Аналіз основних досліджень і публікацій. Різні аспекти досліджуваної проблеми знайшли своє відображення у таких напрямах: розвиток та особливості професійного навчання (С. Батишев, Р. Гуревич, Н. Ничкало, О. Потильчак та інші); розвиток професіоналізму (О. Дубасенюк, Н. Кузьміна, С. Лісова, А. Сбруєва та інші); формування інформаційно-аналітичних умінь (В. Загвязінський, Е. Карпенко, Т. Климова та інші); інформаційно-аналітична компетентність педагогічних працівників у сфері професійнотехнічної освіти (Н. Величко, Л. Майборода, Л. Петренко, В. Ягупов та інші); підвищення ефективності процесу навчання (Ю. Бабанський, Г. Каніщенко, В. Онищук, Ю. Сурмін та інші); використання кейс-методу у навчальному процесі (Л. Вавилова, Е. Гайдамак, Л. Данильчук, Т. Паніна, С. Яковлєва та інші); особливості використання методу проектів (М. Агапова, О. Буйницька, Н. Пахомова, С. Полат та інші).

Однак, у межах досліджуваної нами проблеми впровадження інтерактивних методів і прийомів навчальної діяльності учнів професійно-технічних навчальних закладів потребує подальшої розробки.

Метою статті $\epsilon$ визначити роль інтерактивних методів навчання у формуванні інформаційноаналітичної компетентності учнів професійнотехнічних навчальних закладів.

Виклад основного матеріалу. Реалізація поставленої мети передбачає окреслення поняття інформаційно-аналітичної компетентності учнів ПТНЗ та визначення іiї структурних компонентів.

Інформаційно-аналітична компетентність учнів професійно-технічних навчальних закладів $\epsilon$ складовою їх професійної компетентності, що включає інформаційно-аналітичні знання, навички, вміння, здатності, професійно важливі якості, особистий досвід у сфері пошуку, оцінювання, використання, збереження, аналізу, оформлення й передачі інформації за допомогою різних засобів, методів і форм, що дає змогу оперативно орієнтуватися в інформаційному просторі, брати активну участь у його формуванні і перетворенні, а також успішно реалізовувати інформаційноаналітичну функцію як суб'єктів професійної діяльності у системі виробничих відносин.

Інформаційно-аналітична компетентність $€$ поєднанням двох складових - інформаційної і аналітичної. Інформаційна складова характеризує якість дій майбутнього фахівця, що забезпечують ефективний пошук, структурування інформації, їі адаптацію до особливостей навчального і виробничого процесів і вимог, ефективну роботу 3 інформаційними ресурсами, що дають змогу проектувати рішення виробничих проблем i завдань; регулярну самостійну пізнавальну діяльність, використання комп'ютерних i мультимедійних технологій, цифрових ресурсів у виробничому процесі.

Аналітична складова спрямована на здатність аналізувати, оцінювати й структурувати наявну інформацію, використовувати сучасні методи, форми та засоби ії опрацювання, прогнозувати на основі опрацьованої інформації розвиток певних явищ і процесів у виробничій діяльності, встановлювати причинно-наслідкові зв'язки між різними типами інформації $[6,45-46]$.

Водночас, інформаційно-аналітична компетентність учнів безпосередньо пов'язана з їх професійно важливими якостями й проявляється в діяльності, що зумовлена конкретними обставинами $\mathrm{i}$ ситуаціями, особистісними якостями.

Враховуючи зазначене вище, а також результати аналізу робіт науковців Л. Петренко [5], О. Назначило, В. Ягупова [6] та інших, у структурі інформаційно-аналітичної компетентності учнів професійно-технічних навчальних закладів виділяємо наступні компоненти: изіннісномотиваційний (відображає особистісне ставлення учнів до інформації, усвідомлення ціннісних аспектів інформаційно-аналітичної діяльності та особливостей практичного застосування ii результатів у професійній діяльності; мотивацію здійснення діяльності, зокрема, інтерес до інформаційно-аналітичних дій, потребу у розвитку власного інформаційного потенціалу); когнітивний (комплекс знань теоретичного і технологічного характеру щодо пошуку, обробки і представлення інформації за допомогою різних засобів, зокрема, використання комунікаційних технологій; уявлення про інформаційне середовище, механізми й технологію його функціонування); функиіональний (комунікаційні й аналітичні вміння, зокрема, вміння здійснювати пошук, обробку, представлення і передачу інформації; ефективно використовувати 


\section{ФОРМУВАННЯІНФОРМАЦІЙНО-АНАЛТТИЧНОӦ КОМПЕТЕНТНОСТІ УЧНІВ ПРОФЕСІЙНО-ТЕХНІЧНИХ НАВЧАЛЬНИХЗАКЛАДІВ ШЛЯХОМ АКТИВІЗАЦЇ̈ НАВЧАННЯ}

отримані результати в професійній діяльності; володіння прийомами взаємодії в інформаційному середовищі тощо); рефлексивний (осмислення, самоаналіз, саморефлексія та самооцінка учнем власної навчально-професійної діяльності та їі результатів, визначення на підставі знань і власного досвіду оптимальних методів і прийомів роботи з інформацією, шляхів її організації).

Формування зазначених компонентів передбачає використання у процесі фахової підготовки майбутніх фахівців активних та інтерактивних форм і методів, що базуються на діалозі, кооперації і співробітництві всіх суб' єктів навчально-виробничого процесу. Саме у процесі активного навчання, на відміну від пасивного, учень є суб'єктом навчальної діяльності, вступає у діалог з майстром виробничого навчання, викладачем, одногрупниками, бере активну участь у пізнавальній професійно-орієнтованій діяльності, виконуючи творчі, пошукові, проблемні завдання.

На нашу думку, ключовими методами у контексті нашого дослідження є “кейс-метод" (метод ситуаційного навчання) і метод проектів. Саме їх поєднання $є$ фундаментом для формування інформаційно-аналітичної компетентності учнів професійно-технічних навчальних закладів. Розглянемо зазначені інтерактивні методи більш детально.

Кейс-метод (Case study), або метод ситуаційного навчання (від англ. case “випадок”), - досить складна багатоаспектна технологія навчання, яка являє собою:

- специфічний різновид дослідницькой аналітичної технологї, тобто включає в себе операції процесу дослідження, аналітичні дії. У цьому контексті кейс-метод виступає як спосіб колективного навчання, найбільш важливими складовими якого $є$ робота в групі і підгрупах, взаємний обмін інформацією;

- синергетичну технологію, суть якої полягає в підготовці процедур занурення групи в ситуацію, формуванні ефектів множення знання, обміну відкриттями тощо;

- інтеграцію форм розвиваючого навчання, включаючи процедури індивідуального, групового i колективного розвитку, формування різноманітних особистісних якостей учнів;

- специфічний різновид проектної технологї. У звичайній навчальній проектній технології процес вирішення наявної проблеми здійснюється за допомогою спільної діяльності учнів, тоді як у кейс-методі формування проблеми і шляхів іiі розв'язання відбувається на підставі кейса, який $\epsilon$ одночасно і технічним завданням, і джерелом інформації для усвідомлення варіантів ефективних дій.

- концентрацію досягнень технології “створення усnixy”. Для нього характерна активізація учнів, стимулювання їх успіху, підкреслення досягнень учасників. Саме відчуття успіху виступає однією з головних рушійних сил методу, сприяє формуванню стійкої позитивної мотивації та зростанню пізнавальної активності [4].

У контексті нашого дослідження кейс-метод являє собою техніку навчання, що використовує опис конкретних реальних виробничих ситуацій (кейсів). Учні мають проаналізувати ситуацію, розібратися в суті проблеми, запропонувати можливі рішення і вибрати найбільш ефективне. Завданням "кейс-методу" є не просто передача знань, а набуття здатності справлятися 3 нестандартними ситуаціями. При цьому основна увага приділяється не безпосередньо процесу передачі знань, а розвитку вмінь і навичок аналізу і прийняття рішення.

Метод ситуаційного навчання має дві основні характеристики: аналітичний та пізнавальний аспекти. У контексті використання кейс-методу зміст аналітичної діяльності зводиться до вирішення при аналізі кейсу цілком визначених аналітичних завдань, зокрема: здійснення проблемного структурування, що передбачає виділення комплексу проблем ситуації, їх типології, характеристик, наслідків, шляхів вирішення (проблемний аналіз); визначення характеристик, структури ситуації, іiі функцій, взаємодії 3 навколишнім і внутрішнім середовищем (системний аналіз); з'ясування причин, що призвели до появи даної ситуації, i наслідків іiі розгортання (причинно-наслідковий аналіз); діагностика змісту діяльності у ситуації, іiї моделювання та оптимізація (праксеологічний аналіз); підготовка передбачень щодо імовірного, потенційного і бажаного майбутнього (прогностичний аналіз); вироблення рекомендацій щодо поведінки дійових осіб ситуації (рекомендаційний аналіз); розробка програм діяльності у конкретній ситуації (програмноцільовий аналіз).

Пізнавальний аспект складає основний зміст методу й орієнтований на одержання істинного знання. Метод ситуаційного навчання оперує ситуаційною істиною, що $\epsilon$ максимально прагматизованою. Істинне таке вирішення ситуації, що становить певну сукупність оптимальних рішень, кожне з яких - це пропозиція щодо практичного задоволення потреби, розв'язання конфлікту, вирішення проблеми [2]. 


\section{ФОРМУВАННЯІНФОРМАЦІЙНО-АНАЛТТИЧНОӤ КОМПЕТЕНТНОСТІ УЧНІВ ПРОФЕСІЙНО-ТЕХНІЧНИХ НАВЧАЛЬНИХЗАКЛАДІВ ШЛЯХОМ АКТИВІЗАЦЇ̈ НАВЧАННЯ}

Таким чином, використання кейс-технології охоплює всі компоненти структури інформаційноаналітичної компетентності учнів професійнотехнічних навчальних закладів, хоча акцентує увагу на їі аналітичній складовій. Кейс-технологія дозволяє більш успішно порівняно з традиційною методикою навчання розвивати творчі здібності учнів, формує навички виконання складних завдань у складі невеликих груп, допомагає майбутнім фахівцям успішно оволодіти вміннями аналізувати нестандартні ситуації, самостійно розробляти алгоритми прийняття рішення; сприяє розвитку технічного мислення, умінь вільно орієнтуватися в сучасному виробництві, готовності до плідної професійної діяльності, формуванню таких якостей, як ініціативність i самостійність.

На нашу думку, доцільно представити поєднання кейс-методу 3 іншими методами навчання, зокрема, “мозковим штурмом" i діловою грою.

У зазначеному контексті “мозковий штурм" застосовується як прийом при виникненні в групі певних труднощів в осмисленні ситуації, i спрямований на підвищення пізнавальної активності учнів, хоча в певних випадках може розглядатися як інструмент пошуку нових рішень.

Ділова гра і кейс-метод $є$ принципово спорідненими методами навчання, що створює сприятливі умови для їх поєднання в процесі фахової підготовки. Представимо можливі варіанти такого поєднання: ділова гра включається в опис кейса, вирішення якого передбачає попереднє програвання ситуації з метою здобуття додаткової інформації; у ділову гру обов'язково включена ситуація або навіть декілька ситуацій. В процесі іiі розігрування виникає необхідність опису ситуації, тобто використання кейс-методу. Заздалегідь підготовлений кейс можна використовувати як засіб, спосіб введення учасників в ділову гру. При цьому його осмислення створює своєрідний інтелектуальний, проблемний фон ділової гри [4].

На думку науковців (Л. Вавілової, Т. Паніної [4], Л. Данильчук [2]), необхідність впровадження кейс-методу в практику освіти обумовлена двома тенденціями: по-перше, орієнтацією освіти не стільки на отримання конкретних знань, скільки на формування умінь і навичок розумової діяльності, розвиток здібностей, серед яких особлива увага приділяється здатності до навчання, зміні парадигми мислення, вмінням переробляти величезні масиви інформації; подруге, розвитком вимог до якостей особистості фахівця, який крім задоволення вимог першої тенденції повинен володіти також здатністю адекватно поводитися в різних ситуаціях, вміти системно й ефективно діяти в умовах кризи.

Ситуаційну методику навчання у контексті нашого дослідження доцільно доповнює метод проектів, використання якого зумовлено необхідністю готувати учнів у контексті нової парадигми знань, де особливо цінується інформаційна грамотність; розвивати в них перспективні навички, серед яких: постановка цілей, планування професійної діяльності, самостійне мислення, раціональне вирішення проблем, прийняття оптимального рішення, ефективний пошук, аналіз та оцінка інформації, спільна робота в команді, ефективне спілкування; творчий підхід до справи, висока працездатність.

Метод проектів як базовий елемент проектувального підходу включає у себе сукупність навчально-пізнавальних методів творчого характеру (дослідницьких, пошукових, проблемних тощо), що дозволяють вирішити певну проблему шляхом самостійних дій учнів 3 обов'язковим представленням отриманих результатів у вигляді матеріального проекту.

Провідною ідеєю методу проектів є активне навчання, яке б спиралося на інтереси учня. Важливо показати учням їх особистісну зацікавленість у знаннях, які вони набувають, їх роль та цінність у професійній діяльності. Реалізація зазначеного завдання передбачає постановку проблеми, значимої для учнів, розв'язання якої вимагало використання як набутих, так і нових знань. Учні повинні самостійно розв'язати проблему; вчитель озброїти джерелами інформації, направляти самостійну роботу учнів. Таким чином, робота над проблемою набуває форми проектної діяльності.

В основу методу проектів покладено розвиток пізнавальних та професійних інтересів учнів, умінь самостійно конструювати свої знання, умінь орієнтуватися в інформаційному просторі, розвиток критичного мислення.

Вибір методу проектів як одного 3 ключових у формуванні інформаційно-аналітичної компетентності учнів зумовлений низкою переваг зазначеного методу у контексті нашого дослідження:

- метод проектів спрямований на доцільне поєднання та взаємодію академічних знань та практичних умінь. Учні усвідомлюють необхідність знань (ціннісно-мотиваційний компонент), їх змістового наповнення, алгоритм їх застосування у практичній діяльності (когнітивний компонент); 


\section{ФОРМУВАННЯІНФОРМАЦЙНО-АНАЛТТИЧНОӤ КОМПЕТЕНТНОСТІ УЧНІВ ПРОФЕСЙНО-ТЕХНІЧНИХ НАВЧАЛЬНИХЗАКЛАДІВ ШЛЯХОМ АКТИВІЗАЦІЇ НАВЧАННЯ}

- передбачає розвиток в учнів умінь самостійно здобувати знання, використовувати їх для розв’ язування нових пізнавальних і практичних задач, адаптувати набуті знання та вміння до нових умов професійної діяльності (функціональний компонент), аналізувати i оцінювати результати власної діяльності (рефлексивний компонент);

- сприяє розвитку комунікативних i організаторських умінь, зокрема, вмінь працювати в групах, виконуючи різні соціальні ролі (лідера, виконавця, посередника тощо), вміння організовувати власну професійну діяльність, обирати оптимальні шляхи розв'язку проблеми, враховуючи різні точки зору;

- розвиває здатність до дослідницької діяльності, як складової реалізації професійної діяльності: вміння здійснювати пошук, аналіз необхідної інформації, висувати гіпотези, робити висновки [1].

До використання методу проектів ставляться певні вимоги, а саме: наявність значущої дослідницької, творчої проблеми/задачі, що вимагає інтегрованого знання, пошуку шляхів іiі розв'язання; практична, теоретична, пізнавальна значущість прогнозованих результатів; самостійна (індивідуальна, парна, групова) діяльність учнів; визначення кінцевих цілей спільних/індивідуальних проектів; визначення базових знань і вмінь 3 різних галузей, необхідних для роботи над проектом; структурування змістової частини проекту (з визначенням поетапних результатів); використання дослідницьких методів: визначення проблеми, задач дослідження, що випливають із проблем сформульованої гіпотези щодо їх розв'язання, обговорення методів дослідження, аналіз отриманої інформації, корегування, оформлення кінцевих результатів, підведення підсумків, висновків (використання в ході спільного дослідження методу “мозкової атаки”, “круглого столу”, статистичних методів, творчих звітів, перегляду тощо); результати виконаних проектів повинні бути матеріальними (альбом, газета, Web-сторінка, презентація тощо) [1; 3; 7].

Розробка проекту включає послідовність наступних етапів: виявлення і формулювання загальної проблеми; виявлення часткової проблеми (підпроблеми, ієрархії підпроблем) для певної дослідницької задачі з урахуванням вікових особливостей учнів; презентація ситуацій для виявлення проблеми; формулювання проблеми; формулювання гіпотез; методи збирання і обробки інформації для підтвердження сформульованих гіпотез; накопичення інформації; iï обговорення; перевірка гіпотез; формулювання понять, узагальнень, висновків; впровадження результатів.

Однією з вимог, що ставляться до розробки проекту, є необхідність визначення його соціальної, культурної, економічної значущості. Тобто обрана ідея може бути коректно усвідомлена за умови розгляду в певній системі знань, соціального явища, економічної проблеми тощо, і може “потягнути” за собою цілу серію взаємопов'язаних проектів, що складають єдину тему, проблему, яку доцільно розглядати, аналізувати, вивчати послідовно, проект за проектом, розглядаючи різні іï аспекти. Тому викладач передусім повинен розглянути свою (або учнівську) ідею $з$ цієї позиції [1;7].

Зауважимо, що у контексті нашого дослідження кейс-метод і метод проектів, $є$ ключовими, але мають використовуватися в органічній єдності з іншими методами навчання, в тому числі й 3 традиційними. Важливо підкреслити, що традиційне навчання закладає в учнів нормативне знання, яким повинен володіти кожен учень. Метод проектів вчить пошуку й використанню знань (інформації) в умовах динамічної ситуації, розвиваючи гнучкість і самостійність мислення; метод ситуацій сприяе розвитку критичної рефлексії, кращому розумінню теорії, вчить розв'язувати проблеми і критично їх аналізувати. Проте ефективність їх використання залежить від наявності необхідного нормативного скелета знань, умінь і навичок, на основі яких учень здобуває нові знання, оволодіває новими вміннями.

Однак, як свідчить аналіз практичного досвіду, якщо інтерактивні методи впроваджуються недостатньо продумано і послідовно, без належного методичного забезпечення, теоретичного осмислення й експериментальної перевірки, це призводить до появи певних проблем і ускладнень в організації навчального процесу, а саме: зниження ролі викладача, неекономної витрати навчального часу, відсутності в учнів достатньої мотивації для зазначеного типу навчання тощо. Тому у процесі фахової підготовки учнів доцільно застосовувати заздалегідь розроблені кейси і проекти, що являють собою цілісну програму.

Висновки. Таким чином, використання розглянутих інтерактивних методів у процесі фахової підготовки учнів професійно-технічних навчальних закладів, зокрема, кейс-методу і методу проектів як ключових, у поєднанні 3 іншими традиційними й активними формами $\mathrm{i}$ методами навчання сприяє розвитку всіх структурних компонентів інформаційно- 


\section{ФОРМУВАННЯІНФОРМАЦИЙНО-АНАЛТТИЧНОЇ КОМПЕТЕНТНОСТІ УЧНІВ ПРОФЕСІЙНО-ТЕХНІЧНИХ НАВЧАЛЬНИХЗАКЛАДІВ ШЛЯХОМ АКТИВІЗАЦІЇ НАВЧАННЯ}

аналітичної компетентності майбутніх фахівців як складової професійної компетентності, а отже, забезпечує їх успішне формування.

Серед перспектив наших подальших досліджень - визначення умов ефективного поєднання інтерактивних форм і методів навчання у межах розробки технології формування професійної компетентності майбутніх робітників.

\section{ЛІТЕРАТУРА}

1. Агапова М. Б. Формування професійних інтересів учнів професійно-технічних навчальних закладів у процесі фахової підготовки: дис. на здобуття наук. ступеня канд. пед. наук: спец. 13.00.04 “Теорія та методика професійної освіти” / Агапова Марина Борисівна. - Житомир, 2008. 298 c.

2. Данильчук Л. О. Формування професійноособистісного іміджу майбутніх фахівців фінансово-економічного профілю: дис. на здобуття наук. ступеня канд. пед. наук: спец. 13.00.04 “Теорія та методика професійної освіти” / Данильчук Лариса Олексіївна. - Житомир, 2007. $-267 \mathrm{c}$.

3. Дементієвська Н. П. Телекомунікаційні проекти. Стан та перспективи / Дементієвська Н. П., Морзе Н. В. // Комп'ютер в школі та сім'ї. - 1999. - № 4. - С. 16-19.

4. Панина Т. С. Современные способы активизации обучения : учеб. пособие для студ. высш. учеб. заведений / Т. С. Панина, Л. Н. Вавилова; Под ред. Т. С. Паниной. - М.: Издательский центр “Академия”, 2006. - 176 с.

5. Петренко Л. М. Теорія і методика розвитку інформаційно-аналітичної компетентності керівників професійно-технічних навчальних закладів: дис. на здобуття наук. ступеня д-ра пед. наук : спец. 13.00.04 “Теорія і методика професійної освіти" / Петренко Лариса Михайлівна. - К., 2014. - 581 с.

6. Розвиток інформаційно-аналітичної компетентності педагогічних працівників ПТНЗ: теорія і практика. Монографія / В. В. Ягупов, Н. О. Величко, І. В. Гириловська та ін. За наук. ред. В.В. Ягупова. - К.: ТОВ "НВП Поліграфсервіс", 2014. - 176 с.
7. Intel® Навчання для майбутнього. - К.: Вид. "Нора-прінт", 2006.-320 с.

\section{REFERENCES}

1. Ahapova, M. B. (2008). Formuvannia profesiinykh interesiv uchniv profesiinotekhnichnykh navchalnykh zakladiv u protsesi fakhovoi pidhotovky [The Vocational Training Schools Pupil's Professional Interests Formation in the Process of Professional Preparation]. Candidate's thesis. Zhytomyr, 298 p. [in Ukrainian].

2. Danylchuk, L. O. (2007). Formuvannia profesiino-osobystisnoho imidzhu maibutnikh fakhivtsiv finansovo-ekonomichnoho profiliu [The formation of the professional-personal imaqe of future specialists of financial-economic sphere]. Candidate's thesis. Zhytomyr, 267 p. [in Ukrainian].

3. Dementiievska, N. P. \& Morze, N. V. (1999). Telekomunikatsiini proekty. Stan ta perspektyvy [Telecommunication projects. Condition and prospects]. Computer at school and family, no. 4, pp.16-19 [in Ukrainian].

4. Panina, T. S. (2006). Sovremennye sposoby aktivizatsii obucheniya [Modern ways of activating learning: textbook for educational institutions]. Moscow: Yzdatelskyi tsentr "Akademyia", 176 p. [in Russian].

5. Petrenko, L. M. (2014). Teoriia i metodyka rozvytku informatsiino-analitychnoi kompetentnosti kerivnykiv profesiino-tekhnichnykh navchalnykh zakladiv [The Theory and methodology of information and analytical competence development of vocational school heads]. Doctor's thesis. Kyiv, 581 p. [in Ukrainian].

6. Yahupov, V. V., Velychko, N. O., Hyrylovska, I. V. et al. (2014). Rozvytok informatsiinoanalitychnoi kompetentnosti pedahohichnykh pratsivnykiv PTNZ: teoriia $i$ praktyka. Monohrafiia [Development of informationalanalytical competence of pedagogical workers of the VET: theory and practice.Monograph]. Kyiv: TOV "NVP Polihrafservis", 176 p. [in Ukrainian].

7. Intel® Navchannia dlia maibutnoho (2006). [Training for the future]. Kyiv: "Nora-print" Publ., 320 p. [in Ukrainian].

Стаття надійшла до редакції 31.07.2018

\section{G58080}

“Жайбільша иінність для людини - ие ї̈ власне виховання".

Тригорій Сковорода украӥнський поет, ббілособб

\section{G58080ल2058080}

